\title{
IMPACT OF DIVORCE ON CHARACTER EDUCATION OF CHILDREN (CASE STUDY IN PALU SELATAN DISTRICT)
}

\author{
Ismail \\ UIN Datokarama Palu \\ E-mail: ismailterbaik28@gmail.com
}

\begin{tabular}{|c|c|c|}
\hline Received & Revised & Accepted \\
\hline 4 July 2021 & 2 Agustus 2021 & 20 September 2021 \\
\hline
\end{tabular}

\begin{abstract}
The study aims to explore the impact of divorced on children character education especially in morallity. The study was Qualitative approach with the kinds of case study. The results showed that (1) the causes of divorce in South Palu District, namely economic factors, immaturity of the attitude of husband and wife, lack of communication, infidelity, and factors of domestic violence, (2) The positive impacts are: child have reasonable emotional control, show a good orientation towards the future, have high social relations, and show an independent and responsible attitude. While the negative impact children experience stress or mental pressure, children become aggressive and tend to get naughty, and children often have feelings of guilt, children begin to suffer from high anxiety and fear, children can hate one of their parents. and (3) the efforts made by parents based on research findings are reminding children not to expect anything from others (sincerely), sending children to Islamic boarding schools, inviting children to go on recreation, collaborating with neighbors who are close to children, educating children based on life experiences and education with religion honest, tolerant, disciplined, creative and independent character in children.
\end{abstract}

Keywords: divorce impanct, character education, and character values.

\section{Introduction}

Marriage is a path that all humans will traverse because marriage has been naturalized by Allah SWT. Naturally, if humans want to build a household mahligai to complement human nature itself.

Marriage is a human problem whose various aspects, covering all human life, easily cause emotions and disputes. Therefore there is legal certainty that there has been a marriage that is very necessary, in this case, the occurrence of an aqad (agreement).

It is explained in QS. An-Nur verse 32. 


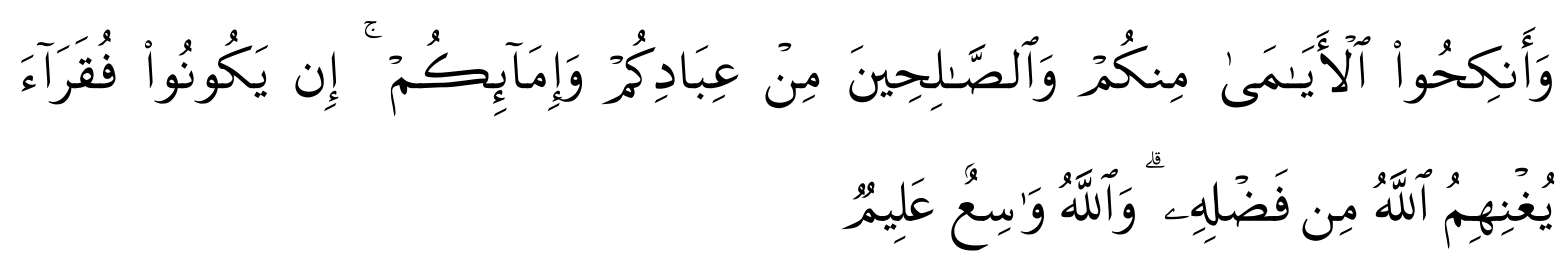

The translation:

Furthermore, marry those who are alone among you and those who are worthy (to build a household) from your male slaves and your female slaves. If they are poor, Allah will enable them with His bounty. Moreover, Allah is All-Wise, All-Knowing. ${ }^{1}$

According to the Law of the Republic of Indonesia number 1 of 1974 concerning Marriage Article 1.

Marriage is an inner and outer bond between a man and a woman as husband and wife to form a happy and eternal family (household) based on God Almighty. ${ }^{2}$

Marriage in Islam has been arranged by Allah and the Messenger of Allah and gives instructions to men who become husbands given a position of power to lead the wife in one command so that they can enforce the Shari'a and discipline to build a household and family. The success of families in instilling good values in children is very dependent on both parents. Parents are very influential in the lives of children, including in the formation of personality, the maintenance of the right religion following the teachings of the Koran. Parents are responsible both in this world and in the hereafter. Parents are the closest teachers for children who must be role models. Therefore, parents are required to set an example and maintain harmony in the family.

According to Comenius, as quoted by Purwanto, besides developing his didactic principles, he said:

How vital family education is for developing children. In his description of the levels of schooling through which children reach maturity, he asserts that the initial level of children's education is carried out in the family, which he calls Scola-materna (Mother's school). ${ }^{3}$

A reality that happened in South Palu District is that various factors trigger the occurrence of divorce. One of the factors is a cheating husband or wife. This was revealed by Mrs. TR "that their divorce was due to her husband cheating, and often came home drunk with alcohol so that sometimes the wife was beaten to a pulp." ${ }^{4}$ From this indication, the beginning of the destruction in the household resulted in a very large impact on children's education. In-Law Number 1 of 1974,

\footnotetext{
${ }^{1}$ Ministry of Religion of the Republic of Indonesia, Al-Qur'an and its Translation, First Printing, (Tangerang: Lentera Hati, 2010), 354.

${ }^{2} \mathrm{Law}$ of the Republic of Indonesia number 1 of 1974 concerning Marriage Article 1.

${ }^{3}$ Salim Purwanto, Theoretical and Practical Education Science (Bandung: Remadja Karya, 2005), 86.

${ }^{4}$ Initials TR, Observation, 24 March, 2020.
} 
which regulates matters related to marriage, among others, stipulates the procedures and reasons for divorce that can be justified. In article 39 it is explained:

1. A divorce can only be carried out in front of a court session in which the person concerned has tried and failed to reconcile the two parties.

2. To divorce, there must be enough reason that husband and wife will not live in harmony as husband and wife.

3. The procedure for divorce before the court is regulated in a separate statutory regulation. ${ }^{5}$

KasuThere are quite a lot of divorces that occur in Palu City, in particular, in South Palu District; this is based on data from annual report documents received by the Office of Religious Affairs (KUA) of South Palu District. Based on the author's initial observations, to obtain divorce data, the author visited the Office of Religious Affairs (KUA) of South Palu District. Then, it was found that marital disputes in South Palu District were relatively high, as seen in the high divorce rate. Especially when compared to other sub-districts in Palu City. In 2018-2020 the divorce rate in South Palu District was 56 pairs of marriages of 143 pairs, and divorce was caused by various things. Moreover, there are also several cases of marital conflict that almost ended in divorce but could still be mediated by the Office of Religious Affairs (KUA) of South Palu District. In an effort to reduce the number of disputes in marriage, the Office of Religious Affairs (KUA) of South Palu District conducts guidance to prospective brides before marriage and after marriage. $^{6}$

AkitchenFor more details regarding the divorce rate in South Palu District, it can be seen from the results of the annual report document on divorce cases received by the Religious Affairs Office (KUA) of South Palu District as follows:

Tabel 1.1.

total divorce at the District KUASouth Palu Tofu 2018 - 2020

\begin{tabular}{|c|c|c|c|c|}
\hline NO & KNOWN & NIKAH & CERAI TALAK & JUMLAH \\
\hline 1 & 2018 & 60 & 17 & 77 \\
\hline 2 & 2019 & 47 & 23 & 70 \\
\hline 3 & 2020 & 36 & 16 & 52 \\
\hline
\end{tabular}

source Data: KUA South Palu District

The impact of divorce is that children often get psychological pressure, namely inferior, naughty, quick to emotion, always late for school, and not coming home on time. This was conveyed by Mrs. SW that "When these two married couples divorced, their child experienced a change in behavior, namely very naughty, going to school was always late, coming home from school was not on time, even though before the divorce their child was the youngest. submissive"7.

\footnotetext{
${ }^{5}$ Law of the Republic of Indonesia number 1 of 1974 concerning Marriage Article 39.

${ }^{6}$ Preliminary Observation of Research Data (Document KUA Kec. Palu Selatan 2020)

${ }^{7}$ Initials SW, Observation, 24 March 2020.
} 


\section{Literature review}

\section{Islamic Concepts in Character Education}

A child in seeking the values of life must receive complete guidance from educators, because according to Islamic teachings when a child is born weak and holy/fitrah, it is the nature around him that will give color to the lifetime value of a child's education, especially education. Therefore, Islam is very concerned about the problem of education for children and provides concrete concepts contained in the Qur'an and the explanation of the Prophet Muhammad in the hadith.

If children's education is far from the Islamic faith, separated from religious teachings, and not related to Allah, then there is no doubt that children will grow up above ungodliness, deviation, misguidance, and disbelief. He will follow the lusts and whispers of the devil, according to his character, physique, desires, and low demands.

The primary fundamental that must be nurtured in the family environment is the principle of monotheism. This is considered a significant prerequisite on character education for children by their parents as a faith identity that must be instilled from an early age by setting an example as the Word of God in Surah alAhzab verse 21:

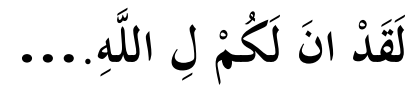

\section{Translation:}

"Verily, there has been in the Messenger of Allah a good role model..." (Qs. alAhzab: 21 $)^{8}$

In the process of child development, there is a phase known as the imitation phase. In this phase, a child always imitates the adults around him, especially his parents or teachers. This exemplary method is very suitable to be applied in this phase. In education, educators (parents and teachers) are not enough to advise a comprehensive sense, but they should set an example, sending children to the mosque while he has never been to the mosque. Lack of words and actions makes parents/teachers have no authority as educators and makes children confused because what they see does not match what they hear.

One form of worship education that must be instilled in a child from an early age is the command to pray and good deeds, which are reflected in the prayer Amar ma'ruf and nahi mungkar also advice in the form of a shield that fortifies someone from failure, namely patience and steadfastness. in Surah Lukman verse 17 Allah swt. Said:

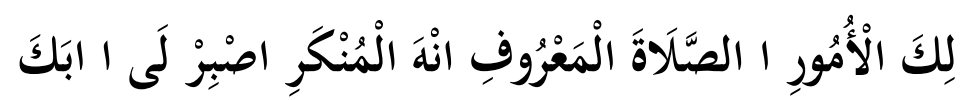

Translation:

Hi my son, establish prayer and call (people) to do good, prevent (them) from doing evil, and be patient with what befalls you. Indeed, that is one of the things that are obligatory (by Allah). (Qs. Lukman:17) ${ }^{9}$

\footnotetext{
${ }^{8}$ Ministry of Religion, Al-Qur'an and translation 420.
} 
Efforts to familiarize children with worship and take care of themselves by prioritizing principles Amar ma'ruf nahi munkar It can be said as a foundation in order to form a child's personality with the character from an early age. The weak condition of young children in parents' care is the same as the condition of parents who are old in the care of children. When Allah obliges children to do good to their parents in return for parents who had treated their children well and worked hard when they were young, automatically parents are also required to do the same thing, namely to treat children well; do not behave that shows boredom and boredom verbally or body language.

\section{Leader in Family}

The leader in a family is the husband, and the husband must be able to guide and nurture his family towards a healthy family sakinah, mawaddah, warahmahwhich is the dream of every family. The husband must be able to be a good priest for his family to create peace and harmony in the family.

Helmawati explained:

"The father as the head of the household has the highest authority in the family, but the highest authority is certainly not intended to oppress or misery his family members, but with that authority, a leader should protect and be responsible to all members of his family in peace, safety, and prosperity. "The father as the head of the household has the highest power in the family. However, the highest power is certainly not intended to oppress or harm his family members. However, with that power, a leader should protect and be responsible for all family members so that they are peaceful, safe, and prosperous. "10

\section{Whereas According to James K. Van Fleet, leadership is}

"The art of influencing and directing means in such way to obtain their willing obedience, confidence, respect, and loyal cooperation in order to accomplish the mission" "Leadership is the art of influencing and moving people in such a way as to earn obedience, trust, respect, and royal cooperation to accomplish tasks. ${ }^{11}$

Therefore, the husband, as a leader in the family, must be able to direct the behavior of his family members towards achieving a specific goal that is better following the advice of Islam. The direction, in this case, means causing family members to act in a certain way or to follow a specific direction.

An understanding of male leadership in the family plays an essential role in building a sakinah family. However, there are differences in interpreting the criteria

\footnotetext{
${ }^{9}$ Ministry of Religion, Qur'an and translation, 412.

${ }^{10}$ elmawati, Managerial skills (Jakarta: Prenada Media, 2007), 76.

${ }^{11}$ James K. Van Fleet, Leadership Management Translated. Ahmad Susanto (Jakarta: Business Partners, 2006), 22.
} 
for leadership in the family. Is leadership absolute for every man or only for confident men who can meet the requirements as stated in the QS. al-Nisa' [4]:34. ${ }^{12}$

\section{Divorce}

Generally, regarding the breaking up of marital relations, Law Number 1 of 1974 concerning Marriage divides the causes of dissolution of marriages into 2 (two) groups, namely as stated in Article 38 or the Compilation of Islamic Law Article 113, marriages can be broken up. because of the following:

1. Death

Islamic marriage law stipulates that divorce will occur automatically if one of the two husbands and wives dies. We are starting from the date of death.

2. Divorce

Two kinds of divorce cause the dissolution of a marriage. Namely, divorce because of talak (divorce) and divorce because of a lawsuit (lawful for divorce). ${ }^{13}$ According to Islamic law, the severance of the marriage bond can be carried out in several ways depending on who wishes or takes the initiative to break the marriage bond. In this case, there are 4 (four) possibilities:

1. The marriage dissolution at the husband's will for specific reasons and his will is stated through certain words or through writing or gestures for husbands who cannot speak. This form of divorce is called talak(الطلاق)(الإق(أ) Divorce whose initiative is from the husband can also be in the form of ila'(الإيلاء) or dhihar (الظهار). It is just that Ila' and dhihar are prologues to the occurrence of divorce, in the sense that if within four months after the husband performs ila' or dhihar, he does not want to return to his wife, the marriage is declared broken.

2. The termination of the marriage at the will of the wife because the wife is unable to continue the marriage because there is something that is considered harmful by her husband, while the husband does not want to divorce his wife. To break this marriage, the wife gives something material to the husband and the husband agrees. The form of divorce which the wife initiates in this way is called khulu'.(الخلع).

3. The termination of a marriage through a judge's decision as a third party after seeing something in the husband or wife which shows that the marital relationship between the two cannot be continued or the marriage carried out by husband and wife violates the law of marriage or does not meet the elements and conditions. The break up of this form of marriage is called Fasakh .(ال) .

4. The dissolution of a marriage by the will of Allah means that one of the husband and wife dies. The death of one party automatically ends the marriage bond. ${ }^{14}$

\footnotetext{
${ }^{12}$ Sri Suhandjati, Male Leadership in the Family: Its Implementation in Javanese Society, Journal of Theology — Volume 28, Number 2, December (2017) 329-350 ISSN 0853-3857, 329.

${ }^{13}$ Law Number 1 of 1974 concerning Marriage

${ }^{14}$ Wise,Inhttp://www.huajiehulan.com/2012/06/forms of breaking up a marriage.html, Accessed 11 March 2020
} 


\section{Impact of divorce on children}

In an unhealthy household, which is problematic and full of quarrels, three categories of children can appear rebellious children who become problems outside. The child who is the victim of a divorced family becomes very naughty because:

1. Have anger, frustration, and want to vent it.

2. In addition, children who are victims of divorce become angry quickly because they see their parents fighting too often. However, anger can also arise because He has to live in tension, and he does not like to live in tension. He had to lose a peaceful, warm life, and he became angry at his parents for giving them this kind of life. Furthermore, when parents divorce, most children live with their mother, which means that something is missing in the child, namely an authority figure, a father figure.

3. Children who are innately sad shut down and become depressed. This child can also lose his social identity. ${ }^{15}$

Therefore, it is not uncommon for them to lie by saying that their parents are not divorced or even avoiding questions about their parents' divorce. There are so many adverse effects of divorce that can appear on children. "Angry at yourself, angry at the environment, so rebellious, impatient, impulsive." It could be that the child will feel guilty (guilty) and consider himself the culprit or the cause of his parent's divorce. Another impact is that the child becomes apathetic, withdrawn, or vice versa, may appear unaffected by his parent's divorce. "Parents should be careful to see if this is a natural reaction because he has matured enough to accept it, or is it just pretending." Children may also be insecure and afraid to establish intimacy with the opposite sex. ${ }^{16}$

\section{Research methods}

According to Taylor by Kahmad that the use of qualitative methods is seen as a research procedure that can be expected to produce descriptive data in the form of written or spoken words of several people and observable behavior. ${ }^{17}$ Therefore, in discussing a problem, especially in dissertation research, it indeed refers to the object or target to be studied so that in discussing the problem, there is no confusion in the research. The reason the researcher uses qualitative research in this dissertation research is, as stated by Lexy J. Moleong that qualitative methods are used because of several considerations:

First, adopting qualitative methods is more manageable when dealing with multiple realities; second, this method presents the nature of the relationship between the researcher and the respondent directly; third, this method is more sensitive and more adaptable to the many sharpening of mutual influences and the patterns of values encountered. ${ }^{18}$.

\footnotetext{
${ }^{15}$ Ibid, 15

${ }^{16}$ Ibid, 16

${ }^{17}$ Dadang Kahmad, Religious Research Methods (Bandung: CV. Pustaka Setia, 2011), 97.

${ }^{18}$ Lexy J. Moleong, Qualitative Research Methodology, Cet. XVII (Bandung: PT. Teen Rosdakarya,
} 2002), 5 . 
In addition to the considerations mentioned above, researchers use qualitative methods because the problem under study is natural. This is in line with Lexy J. Moleong, who said that "qualitative research is researching a natural

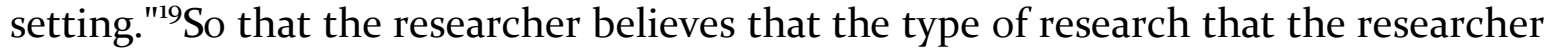
uses in the context of compiling this scientific work is appropriate with the title of the dissertation that the researcher intends.

\section{Overview of Research Locations.}

Based on its geographical position, South Palu has boundaries in the north: East Palu District, east: Mantikulore District, south: Sigi Regency, west: Tatanga District, with $+27.38 \mathrm{~km}^{2}$. The topographic condition of the South Palu District is located extending from west to east, consisting of 5 sub-districts, all of which can be passed by two-wheeled and four-wheeled vehicles. At the same time, the furthest distance from this sub-district to the village is the Petobo Selatan sub-district every $3.5 \mathrm{~km}$, while the closest is the North Birobuli sub-district along $0.2 \mathrm{~km}$. The topography of the southern Palu sub-district is primarily plains with a percentage of $75-100 \%$, hills $0-25 \%$, and mountains $0 \%$ with a height of $+90-180 \mathrm{~m}$ above sea level, with an average rainfall of $41.1 \mathrm{~mm}$ per year. ${ }^{20}$

South Palu District administratively consists of 5 sub-districts. led by the Camat as a government coordinator who is assisted by the lurah of South Palu, South Palu sub-district consists of 5 kelurahan, and each kelurahan is divided into several RW and RT, namely South Birobuli Village, Petobo Village, North Birobuli Village, North Tatura Village, and South Tatura Village. . The population of South Palu District until December 2020 is: $71,55^{2}$ people consists of Male-male: 35,915 souls Female: 35,637 souls Consists of $71,55^{2}$ souls $^{21}$

\section{Factors Causing Divorce in South Palu District Economic Factor}

One of the factors that cause the condition of families living in the poverty line. To lighten the burden on her parents, the woman married her lover too soon so that the woman would not depend on her parents anymore, while the couple's economic situation was too young, and she could not afford a job that required physical strength. Economic factors are one of the factors that cause this to happen. Interviews with Initials $W$ who married at the age of 17 and divorced at the age of 18 are as follows:

After marriage, my husband and I lived at my parents' house and then a,fter 2 months of marriage I became pregnant a few months later I gave birth automatically, there were a lot of exmanyhat needed to be needed but my hus,band didn't wantdid notrk anymore so my mother and I advised him gently. However, my husband did not accept my advice, and my mother then my husband was angry and went to his parent's house; after that my husband

\footnotetext{
${ }^{19}$ Ibid, 4.

${ }^{20}$ South Palu District Document 2020.

${ }^{21}$ South Palu District Document 2020.
} 
never saw me again and did not provide for me that's where I filed for divorce with my husband. ${ }^{22}$

From the results of the interview above researcher draw the conclusion that economic factors are included in the decision to divorce at a young age, and on average, this couple has a sumi who works as a farmer to support his family.

\section{Factors of Immaturity of Husband and Wife's Attitude}

A person's attitude, one of which is seen from egoism or a partner who is always dominant who wants to win alone, is a bad trait possessed by humans, this trait also triggers the impact of divorce between husband and wife.

Interview with Initial $\mathrm{R}$ who married at the age of 17 :

I divorced because there was no longer a match between me and my exhusband, we also often quarreled in the household even though it was trivial, and that made me no longer strong enough to carry out domestic life with him so I asked for a divorce. ${ }^{23}$

From the results of the interviews above, the difference between-Differences that were previously invisible will surface. If this difference is not resolved when it comes to the principal aspects of life, then there is a possibility that the life of the household is threatened. There are differences in the principles of a large background of life to limit it, if it is ignored and there is no understanding from both parties and there is no desire to improve and overcome it, the gap that will separate the two individuals is also increasing which leads to divorce.

\section{Lack of communication} husband:

Interview with Initial $\mathrm{M}$ who married at the age of 18 and has divorced her

I divorced my husband because there was no openness of my husband with me, every time I asked my husband my silence so that my husband often closed himself to me, he never came home again for months so I asked my husband for divorce and he agreed. ${ }^{24}$

Based on the interview results above, it is known that men-Men and women differ in their handling of emotional problems. The vulnerable thing for men is that men tend to maintain their ego and self-esteem, are not strong enough to be criticized by their wives continuously, and are silent. Things that are vulnerable for women tend to be emotional, like to criticize and cry.

\footnotetext{
${ }^{22}$ Initial W, Housewife, "Interview", (Resident's House/Initial W), 26 August, 2020.

${ }^{23}$ Initial R, Housewife, "Interview", (Resident's House/Initial R), 31 August, 2020.

${ }^{24}$ Initials M, Housewife, "Interview," (Resident's House/Initial M), 31 August 2020.
} 


\section{Infidelity Factor}

As happened to Mrs. S (22 years old), whose address is at Kec. South Palu. Ibu $\mathrm{S}$ married in 2011 and divorced in 2013. The following are the results of an interview with Ibu $S$ about the factors causing the divorce:

I filed for divorce with the Palu Religious Court in 2013 because my husband had an affair with another woman. I am very disappointed with my ex-husband because he cheated on me. Which woman, sir, is willing to see her husband having an affair with someone else. Even though we have been blessed with one daughter whose name is DA ( 5 years old). ${ }^{25}$

According to Ms. S's narrative, her household became disorganized because her ex-husband had an affair. The money from her husband's work is not given to the family but is used to have fun with other women. At first, I could not believe that my husband had done this. However, after seeing it for myself, I finally believed it. Feeling hurt, Mrs. S finally could not forgive her husband's mistakes and finally, Mrs. $\mathrm{S}$ filed for divorce.

\section{Domestic Violence}

As happened to Mrs. W (27 years old) having her address at Kec. South Palu. He has been blessed with one son named A (10 years). The following are the results of an interview with Mrs. W about the factors that cause divorce:

At first, my marital relationship was fine, sir, but lately, my husband is often angry with me, for which I don't understand the reason. I try to be patient, but I am not strong. Every problem must end in a dispute. Usually, I have disagreements because the results of their work are used alone without being shared with the family. So I am ashamed, sir, with my family. Even though I still ride with my family. Besides that, I am also ashamed of my son, sir, every day we always fight and finally I filed for divorce to the Palu Court. ${ }^{26}$

\section{Efforts Made in Divorce Settlement in South Palu District}

In dealing with divorce in The Office of Religious Affairs (KUA) of South Palu District based on the data and facts obtained there are several efforts, namely as follows:

1. Peimproving the quality of family development through the sakinah family movement

2. PeDistrict level sakinah family choice

3. Peimproving the quality and professionalism of implementing services in the field of advisory, coaching and marriage

4. Improving legal consulting services, marriage and family advisory

5. Completing the guidebook for implementing sakinah family education.

6. Strive for marriage and family magazines to be widely disseminated to the public. $^{27}$

\footnotetext{
${ }^{25}$ Initial S, Housewife, "Interview," (Resident's House/Initial S), 1 September, 2020.

${ }^{26}$ Initial W, Housewife, "Interview", (Resident's House/Initial W), 3 September, 2020.

${ }^{27}$ South Palu District KUA Document, 2020
} 


\section{The Impact of Parental Divorce on Children's Character Education}

1. Development of Child Behavior Due to Parental Divorce in Kec. South Hammer
a. Children Experiencing Stress or Inner Pressure
b. Children become aggressive and tend to be naughty
c. Children often feel guilty
d. Child Starts Suffering High Anxiety And Fear
e. Child Hates One of His Parents.

\section{Changes in behavior Children Due to Parental Divorce in Palu City}

Based on the research above, the researchers review one by one the results of interviews and research with the following description:

a. Denial

Denials are: children who are victims of parental divorce will usually deny that nothing happened between the father and mother.

b. Shame

Shyness is a form of fear characterized by withdrawal from relationships with other people who are unknown or do not meet often. Shame is always inflicted by humans, not by animals or situations.

c. Sadness

Adolescents who initially feel comfortable with their parents will certainly feel sad if their parents separate or divorce and maybe the teenager will feel lost, in contrast to the teenager who initially did not really expect the presence of parents because many children today no longer appreciate the presence of parents, and that can be caused by too free association

d. Children Be Quiet

Children who are victims of divorce tend to change their usually cheerful attitude to become quiet and even seem distant from the surrounding community. Parental divorce is estimated to affect children's learning achievement, both in the field of religious studies and in other fields. One of the basic functions and responsibilities of parents towards their children is to take their education seriously.

\section{Positive Impact of Parental Divorce on Children's Character}

a. Meshow a good attitude towards the future orientation

One of the positive impacts caused in part ditionIn a positive way, sometimes children increase their concentration in learning, are enthusiastic about building a future, which is reflected by learning activities outside of school hours.

b. Meshow an independent and responsible attitude

KemaSelf-reliance indicates a belief in one's own ability to solve a problem that is being faced so that individuals will eventually be able to think objectively. as in the following interview, children of divorced victims have si independent and responsible hood. 


\section{Brand Methods of Parents in Educating Children Victims of Divorce in Kec. South Hammer}

Efforts made by parents based on research findings are reminding children not to expect anything from others (sincerely), sending children to Islamic boarding schools, inviting children for recreation, collaborating with neighbors who are close to children, educating children based on life experience, and educating with science. Religion. In addition, the method used in shaping children's character education is by forming honest, tolerant, disciplined, creative, and independent characters in children.

\section{Conclusion}

1. Factors that cause divorce in South Palu District, namely economic factors, factors of the immaturity of husband and wife attitudes, lack of communication, infidelity factors, and factors of domestic violence (KDRT), as for The efforts made in tackling divorce are:

a. Conducting guidance and socialization by inviting the community to the KUA of South Palu District, maximizing the counseling carried out so as to prevent marital conflicts, collaborating with other agencies such as the Palu City Government, Puskesmas, and the South Palu District Government, sending prospective brides and married couples to activities guidance and guidance held by the Office of the Ministry of Religion at the City/Regency level, regional level or held by other agencies (BKKBN), provides insight to the general public in Friday sermons, marriage sermons, and other possible events.

b. Family counseling by providing insight into the household. This provision is delivered through premarital guidance programs or courses for prospective brides and families with problems, provides reflection and awareness about the importance of mental preparation to become husband and wife as well as readiness to become parents of children who will be born to them, provide warnings and advice that marriage is worship that contains the meaning of a sacred agreement and will give birth to a mandate for married couples.

2. The impact of parental divorce on children's character education has a positive and negative impact. The positive impacts are: child have reasonable emotional control, meshow a good orientation towards the future, have high social relations, and show an independent and responsible attitude. While the negative impact children experience stress or mental pressure, children become aggressive and tend to get naughty, and children often have feelings of guilt, children begin to suffer from high anxiety and fear, children can hate one of their parents. In addition, children whose parents divorced tend to have behavioral changes from before their parents divorced, namely in the form of denial, shame, sadness, and children being quiet.

3. Efforts made by parents based on research findings are reminding children not to expect anything from others (sincerely), sending children to Islamic boarding schools, inviting children for recreation, collaborating with neighbors who are close to children, educating children based on life experience and educating with 
science. Religion. In addition, the method used in shaping children's character education is by forming honest, tolerant, disciplined, creative and independent character in children.

\section{REFERENCES}

Ministry of Religion of Indonesia, Al-Qur'an and its Translation, First Printing Tangerang: Heart Lantern, 2010.

Law of the Republic of Indonesia number 1 of 1974 concerning. Article Marriage 1. Purwanto, Salim. Theoretical and Practical Education Science. Bandung: Remadja Karya, $\quad 2005$.

Elmawati.Managerial skills.Jakarta: Prenada Media, 2007.

Van Fleet, James K. Leadership Management Translated. Ahmad 'Susanto. Jakarta: Partner Effort, 2006.

Suhandjati, Sri. Male Leadership in the Family: Its Implementation in Javanese people, Journal of Theology - Volume 28, Number 2, December （2017) 329-350 ISSN o853-3857.

Arif, Dalamhttp://www.huajiehulan.com/2012/o6/forms of breaking up a marriage .html, Accessed 11 March, 2020

Ahmad, Dadang. Religious Research Methods. Bandung: CV. Faithful Library, 2011.

Moong, Lexy J. Qualitative Research Methodology, Cet. XVII. Bandung: PT. Rosdakarya Youth, 2002. 